\title{
PELATIHAN PEMBUATAN BIOGAS DARI KOTORAN SAPI DI DESA PONDOK KELAPA
}

\section{TRAINING ON MAKING BIOGAS FROM MANURE IN PONDOK KELAPA VILLAGE}

\author{
Oleh: \\ I Nyoman Candra, Elvinawati, Amrul Bahar
}

\begin{abstract}
The People of Pondok Kelapa mostly work as farm laborers, fishermen and farmers. People are still using raw wood fuel in cooking that has a negative impact in terms of health. LPG fuel is actually good for cooking, but it is relatively expensive. For that need to look for alternative fuels made from materials that are easy to obtain. This service activities such as training for making biogas from cow dung in the village of Pondok Kelapa. Biogas is a mixture of methane and carbon dioxide gas derived from anaerobic fermentation of organic substrates. In this activity, firstly conducted a survey and preparation. Furthermore held counseling, and the last is a core activities including the tool installation and biogas production. This activity produces biogas which initially resulted in a rather small flame. But after his gas collected, the gas produced is large enough. From these activities, the village of Pondok Kelapa succeeded in making biogas from manure.
\end{abstract}

Keywords: biogas, cow manure, fermentation, anaerobic

\section{PENDAHULUAN}

Desa Pondok Kelapa merupakan salah satu Desa di Kecamatan Pondok Kelapa Bengkulu Tengah. Sebagian besar masyarakat bekerja sebagai buruh tani/kebun, nelayan dan peternak. Sistem penerangan dari listrik sudah tersedia. Walaupun sebagian besar masyarakat pondok kelapa sudah menggunakan listrik, akan tetapi beberapa kegiatan yang bisa dikerjakan dengan listrik masih dilakukan secara tradisional misalnya memasak. Warga Desa Pondok Kelapa masih menggunakan kayu bakar dalam memasak. Masyarakat yang menggunakan gas elpiji untuk memasak juga masih sedikit dikarenakan daya beli masyarakat yang masih rendah mengingat sebagian masyarakat bekerja sebagai buruh dan nelayan.

Penggunaan kayu bakar untuk memasak memiliki resiko terhadap kesehatan yaitu asap yang dihasilkan dapat menimbulkan penyakit saluran pernapasan dan yang lebih berbahaya adalah dihasilkannya senyawa dioxin dalam pembakaran yang dapat menyebabkan kanker. Penyakit yang disebabkan oleh senyawa dioxin tidak dirasakan langsung ketika terpapar asap pembakaran kayu bakar tersebut tetapi memerlukan proses. Karena sebagian besar Masyarakat Desa Pondok Kelapa bekerja sebagai buruh dan nelayan, daya beli masyarakat masih cukup rendah. Salah satunya dalam hal penggunaan gas elpiji dalam proses memasak. Apalagi setelah terjadi kenaikan gas elpiji di awal tahun 2014, 
masyarakat sudah jarang yang menggunakan gas elpiji lagi.

Gas elpiji adalah gas yang komponen utamanya adalah gas metana (gas rawa). Gas ini salah satunya bisa dihasilkan dari fermentasi kotoran ternak misalnya sapi. Sehingga kelangkaan gas elpiji yang dihasilkan dari minyak bumi yang diproduksi oleh PERTAMINA bisa kita ganti dengan memproduksinya dari limbah organik misalnya kotoran ternak yang bisa kita pakai sebagai bahan bakar. Gas ini dikenal dengan BIOGAS. Biogas merupakan campuran gas yang mudah terbakar yang terbentuk melalui dekomposisi material organik dalam lingkungan anaerobik dan sedikit oksigen (Nutiu, 2014). Campuran gas dalam biogas adalah metana dan karbondioksida. Selain itu terdapat juga hidrogen sulfida (Culhane). Proses dekomposisi senyawa organik menjadi biogas berlangsung di dalam tempat yang disebut digester. Produksi biogas ini memiliki beberapa keuntungan yaitu: kualitas limbah meningkat, sumber energi terbarukan dan menambah pendapatan petani/peternak (Bavutti, et.al., 2014).

Dengan melihat kondisi Desa Pondok Kelapa yang masih banyak yang menggunakan kayu bakar dalam memasak ini, maka kami bermaksud untuk memberi pelatihan kepada Masyarakat Desa Pondok Kelapa dalam membuat Biogas dari kotoran sapi, mengingat masyarakat di sini banyak yang memelihara sapi.

\section{METODE PENGABDIAN}

Kegiatan ini dilaksanakan di Desa Pondok Kelapa Kecamatan Pondok Kelapa dari Bulan Mei sampai Nopember 2014. Mitra dalam kegiatan ini adalah masyarakat desa Pondok kelapa khususnya Kelompok Peternak Mutiara Hijau. Pemilihan mitra ini dilakukan mengingat cukup banyaknya sapi yang dipelihara oleh kelompok ternak ini dan juga kotoran sapi yang potensial untuk dijadikan biogas.

Kegiatan ini dilakukan dalam beberapa tahap yaitu: Persiapan, penyuluhan, instalasi alat dan pembuatan biogas. Pada tahap persiapan, peneliti melakukan survey ke lokasi untuk menentukan lokasi instalasi biogas. Di samping itu juga dilakukan diskusi dengan kepala desa. Pada tahap persiapan juga disiapkan alat-alat yang diperlukan untuk kegiatan ini. Setelah itu dilakukan penyuluhan yang berupa pemaparan/presentasi tentang pembuatan biogas. Kemudian setelah penyuluhan, dilakukan instalasi alat. Alat yang diinstal adalah digester, lubang pemasukan, lubang pengeluaran dan penyaluran gas dari digester ke kompor. Digester ditanam di dalam tanah. Volume yang digester adalah $2 \mathrm{~m}^{3}$. Dari 3 tipe digester (Pambudi, 2008), peneliti menggunakan digester tipe balon. Lubang pemasukan memiliki ukuran $50 \mathrm{~cm}$ x $50 \mathrm{~cm}$ x $50 \mathrm{~cm}$. Sedangkan lubang pengeluaran ini dibuat dengan ukuran $1,5 \mathrm{~m} \times 1,5 \mathrm{~m} \times 1,5 \mathrm{~m}$. Setelah itu dilakukan proses pembuatan biogas dari kotoran sapi.

Pembuatan Biogas dari kotoran sapi dilakukan dengan mencampur kotoran sapi yang masih baru dengan air dengan perbandingan kotoran sapi: air adalah 1:1 (Anis). Campuran ini kemudian dimasukan ke dalam digester melalui lubang pemasukan. Pengisian dilakukan tiap hari sampai penuh. Gas yang terbentuk disalurkan ke penampung gas kemudian dibagi- 
bagi ke rumah yang lain melalui pipa. Gas dari penampung gas disalurkan ke kompor dan dapat digunakan untuk memasak.

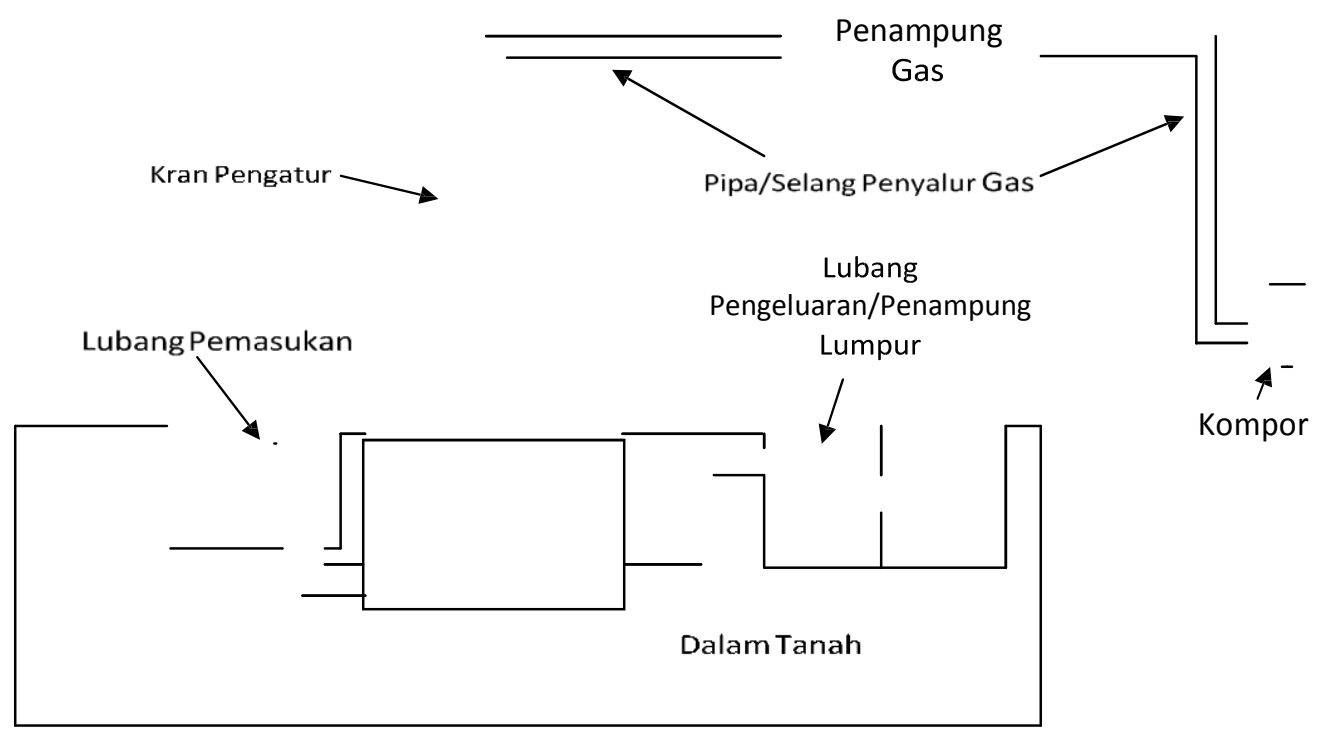

\section{HASIL DAN PEMBAHASAN}

Sebelum acara pelaksanaan kegiatan, dilakukan berbagai persiapan untuk kelancaran acara. Persiapan yang dilakukan adalah melakukan survey ke lokasi. Survey yang dilakukan meliputi konsolidasi dengan Kepala Desa Pondok Kelapa mengenai tempat/lokasi kegiatan yang akan dilakukan. Setelah dilakukan diskusi dengan kepala desa, maka diputuskan untuk memusatkan acara kegiatan di kelompok peternak sapi yang diberi nama mutiara hijau. Jumlah sapi yang ada di kelompok ternak ini cukup banyak yaitu sekitar 60 ekor sapi.

Kotoran yang dihasilkan juga cukup banyak, sehingga meskipun di lokasi lain dipondok kelapa juga memilihara sapi, kepala desa menganjurkan untuk memusatkan kegiatan ini di Kelompok Ternak ini. Disamping itu juga dilakukan diskusi tentang teknis pelaksanaan kegiatan. Persiapan yang lain adalah menyiapkan dan mengadakan peralatan yang diperlukan dalam kegiatan ini. Material-material yang disiapkan adalah meliputi bahan-bahan untuk kegiatan penyuluhan dan presentasi tentang pembuatan biogas dan bahan-bahan untuk kegiatan praktek pembuatan biogas. Bahan-bahan yang disiapkan dalam acara penyuluhan adalah berupa ATK. Sedangkan alat-alat untuk kegiatan praktek pembuatan biogas adalah alat-alat untuk membuat digester, lubang pemasukan, lubang pengeluaran dan alat-alat untuk menyalurkan gas dari digester ke dapur.

\section{Penyuluhan Pembuatan Biogas}

Kegiatan ini berupa pemaparan atau presentasi tentang biogas dan cara pembuatan biogas dari kotoran sapi. Kegiatan ini dilakukan pada tanggal 16 Agustus 2014 di rumah ketua kelompok ternak Desa Pondok Kelapa. Kegiatan ini diikuti oleh 17 orang warga yang 
merupakan perwakilan warga Desa Pondok Kelapa. Materi yang disampaikan meliputi pengertian biogas, prinsip pembuatan biogas, bahan-bahan yang bisa dijadikan biogas, dan teknik pembuatan termasuk peralatan dan bahan yang diperlukan. Materi yang disampaikan diprint dan dibagikan kepada para peserta.

Kegiatan ini berjalan dengan lancar dan para peserta sangat antusias dalam mengikutinya. Hal ini terlihat dari para peserta yang mengikuti kegiatan sampai akhir acara dan tidak ada yang beranjak meninggalkan tempat acara. Disamping itu juga antusiasme peserta terlihat dari banyaknya pertanyaan yang diajukan oleh peserta ke pembicara. Dari beberapa pertanyaan, kebanyakan mereka menanyakan tentang teknik merangkai alatnya.

\section{Kegiatan Praktek Pembuatan Biogas dari Kotoran Sapi}

Kegiatan praktek pembuatan biogas ini memerlukan waktu yang cukup lama yaitu sekitar 1 bulan mulai dari menginstalasi alat-alatnya sampai proses pembuatan biogas. Instalasi pertama yang dilakukan adalah instalasi digester. Digester ini adalah tempat utama proses pembuatan biogas. Digester yang digunakan dalam kegiatan ini terbuat dari polimer yang tahan karat dan tidak mudah pecah. Volume digester yang digunakan adalah $2 \mathrm{~m}^{3}$. Alat ini di tanam di dalam tanah untuk memudahkannya dalam menginstalasi dan menghubungkannya dengan bagian yang lain seperti lubang pembuangan dan lubang pemasukan. Penempatan digester di dalam tanah juga dilakukan untuk mencegah gangguan dari luar. Instalasi digester ini memerlukan waktu hampir 1 minggu.

Bagian lain yang selanjutnya dibuat adalah lubang pemasukan. Pada kegiatan ini lubang pemasukan dibuat agak dekat dengan kandang supaya lebih mudah dalam pemasukan kotoran sapi. Lubang pemasukan yang dibuat berukuran $50 \mathrm{~cm}$ x $50 \mathrm{~cm}$ x $50 \mathrm{~cm}$. Lubang pemasukan ini dihubungkan dengan digester melalui pipa PVC diameter 3 inchi. Disamping lubang pemasukan, bagian yang tidak kalah penting adalah bagian pengeluaran. Bagian pengeluaran ini dibuat untuk menampung sisa hasil fermentasi. Ketika gas terbentuk di dalam digester, maka gas ini akan menekan sisa kotoran hasil fermentasi keluar. Sama halnya dengan lubang pemasukan, lubang pengeluaran ini juga dihubungkan dengan digester melalui pipa PV diameter 3 inchi. Lubang pengeluaran ini jangan sampai tersumbat oleh kotoran sisa fermentasi. Lubang pengeluaran ini dibuat dengan ukuran 1,5m x 1,5m x 1,5m.

Pengerjaan selanjutnya adalah mengalirkan gas ke penampung gas. Penampung gas yang dipakai adalah plastik. Gas yang terbentuk di dalam digester dialirkan ke penampung gas melalui pipa PVC diameter $3 / 4$ inchi. Dari penampung gas baru kemudian dialirkan ke kompor. Pengerjaan instalasi dilakukan oleh warga setempat di bawah bimbingan peneliti. Peneliti menyediakan alat-alat yang dibutuhkan dalam kegiatan ini.

Setelah semua bagian sudah diinstal, baru dilakukan proses pembuatan biogas. Pembuatan biogas dilakukan dengan memasukan kotoran sapi ke dalam digester. Kotoran sapi dicampur dengan air dengan perbandingan 1:1. Pengisian dilakukan sampai digester penuh. Pada hari ke -9 sudah terbentuk gas tapi bukan gas metana tapi gas karbondioksida. Gas metana yang diinginkan baru terbentuk pada hari ke-13 atau selama 2 minggu mulai dari fermentasi. Menurut Saedi (2008), produksi biogas sudah mencapai relatif konstan pada 
hari ke-10.

Pada awalnya, api yang timbul dari kompor nyalanya kecil sekali. Penyebabnya adalah gas nya yang keluar sedikit. Tadinya gas dari digester langsung disalurkan ke kompor. Kemudian setelah gas dari digester ditampung dulu di plastik trus dialirkan ke kompor, baru kemudian gas yang dihasilkan lebih besar dan nyala yang dihasilkan lebih besar. Dengan adanya kegiatan ini, masyarakat Pondok Kelapa sudah mampu membuat sendiri Biogas dari kotoran sapi.

\section{KESIMPULAN}

Dari hasil kegiatan pengabdian di lapangan, dapat disimpulkan:

1. Pelatihan ini berhasil membuat biogas dari kotoran sapi.

2. Dengan adanya kegiatan pengabdian yang dilakukan ini, masyarakat Pondok Kelapa mampu membuat sendiri biogas dari kotoran sapi.

\section{UCAPAN TERIMA KASIH}

Ucapan terimakasih kami sampaikan kepada:

1. Lembaga Penelitian dan Pengabdian (LPPM) Universitas Bengkulu (Unib) yang telah mendanai pengabdian ini melalui dana BOPTN tahun anggaran 2014.

2. Kepala Desa Pondok Kelapa yang sudah mendukung pelaksanaan kegiatan ini.

3. Pihak-pihak lain yang tidak bisa kami sampaikan satu persatu.

\section{DAFTAR PUSTAKA}

Bavuti, M., et.al., 2014, Thermal Stabilization of Digesters of Biogas Plants by Means of Optimization of The Surface Radiative Properties of The Gasometer Domes, Energy Procedia. 45 (2014) 1344-1353.

Culhane, T.H., Biogas Digester. Module for A Decentral Autonomous Energy Supply, Tamera, Solar Village Valerio Marazzi - ARCò.

Nutiu, E., 2014, Anaerobic Purification Installation with Production of Biogas and Liquid Fertilizers, Procedia Technology 12 (2014) 632-636.

Pambudi A.N., 2008, Pemanfaatan Biogas Sebagai Energi Alternatif, Dikti.

Seadi, T.A., et.al, 2008, Biogas, Handbook, University of Southern Denmark Esbjerg, Niels Bohrs Vej 9-10, DK-6700 Esbjerg, Denmark. 

